\title{
Spatiotemporal Portrait of the Quality of Water Supplied by REGIDESO/Butembo, Democratic Republic of the Congo
}

\author{
Phalek Kasereka Katswangene ${ }^{1 *}$, Woto Réné Oleko², Malumba Zoé-Arthur Kazadi² \\ ${ }^{1}$ Faculty of Agriculture, Adventist University of Lukanga, Butembo, Democratic Republic of the Congo \\ ${ }^{2}$ Department of Biotechnology, Faculty of Sciences, University of Kisangani, Kisangani, \\ Democratic Republic of the Congo \\ Email: *kphalek@gmail.com
}

How to cite this paper: Katswangene, P.K., Oleko, W.R. and Kazadi, M.Z.-A. (2021) Spatiotemporal Portrait of the Quality of Water Supplied by REGIDESO/Butembo, Democratic Republic of the Congo. Advances in Microbiology, 11, 225-242.

https://doi.org/10.4236/aim.2021.115017

Received: March 14, 2021

Accepted: May 11, 2021

Published: May 14, 2021

Copyright (c) 2021 by author(s) and Scientific Research Publishing Inc. This work is licensed under the Creative Commons Attribution International License (CC BY 4.0).

http://creativecommons.org/licenses/by/4.0/

\begin{abstract}
Access to drinking water is still a daily struggle for millions of people living mainly in developing countries. As a matter of concern, the main problem with regard to the use of safe drinking water mainly concerns its physicochemical and microbiological quality. This study has been carried out with the aim of contributing to a better understanding of the spatiotemporal variability of the quality of the water supplied by two drinking water distribution system of the REGIDESO in the city of Butembo (DR Congo). Its target is to have a view on its evolution in a period of six months even after the combination of its two networks. The methodology hinges around the microbiological and physicochemical analysis of the waters of eight sites identified on these networks. It results from this study that almost the treated water samples presented values, which did not comply with the WHO quality guidelines for many microbiological physicochemical parameters. Thus, the means of bio-indicators numbers are as following: Germs revivable at $37^{\circ} \mathrm{C}(29.36>10 \mathrm{CFU} / \mathrm{ml})$, total coliforms $(21.89>0 \mathrm{CFU} / \mathrm{ml})$, thermo-tolerant coliforms $(3.53>0 \mathrm{CFU} / \mathrm{ml}$, $) E s$ cherichia coli $(1.25>0 \mathrm{CFU} / \mathrm{ml})$ and enterococci $(0.14>0 \mathrm{CFU} / \mathrm{ml})$ while, for the Salmonella and Shigella $(0.3056>0 \mathrm{CFU} / \mathrm{ml})$. In addition, only the $3 / 5$ (e.g. $60 \%$ ) of the mean numbers of Enterococci and numbers of Salmonella \& Shigella of the treated water samples fit WHO norms. Moreover, seven physicochemical parameters presented general averages far from the admissible maximal values (AMV). There are Ammonia (1.67>0.5 mg/L), Ammonium $(0.32>0.3 \mathrm{mg} / \mathrm{L})$, Iron $(0.36>0.3 \mathrm{mg} / \mathrm{l})$, Nitrate $(55.94>50 \mathrm{mg} / \mathrm{L}), \mathrm{pH}(6.03$ $<6.5-8.5)$, Water Temperature $\left(21.12>8^{\circ} \mathrm{C}-15^{\circ} \mathrm{C}\right)$ and Turbidity $(6.57>5$ N.T.U). This reveals a high exposure of the population of Butembo to the health risk related to the use (consumption) of this water.
\end{abstract}




\section{Keywords}

Water Quality, Microbiological Analysis, Physicochemical Analysis, Water Networks, REGIDESO

\section{Introduction}

After Oxygen, water is the most essential material for life. Without it, human communities cannot neither live nor develop their economy. A daily intake of good quality of water in sufficient quantity is essential for health [1] [2] [3]. Nowadays, the quality of water is deteriorating more and more in the networks [4] and leads to a human health problem [5]. Due to anthropic activities, water has become the receptor and vector of many substances and pathogenic germs that pollute the environment and infect our health [6]. The quality of the water distributed sometimes varies in an alarming manner in many developing countries, which still pay a heavy price from hydric diseases [7], even in certain developed countries [8]. Then raise hydric diseases, particularly in many sub-Saharan countries [1] [5], including DR Congo.

It is known that changes in quality of water characteristics are due not only to anthropic factors, but also to combined natural processes. Hydrologic conditions, topography, lithology, climate, precipitations, hygienic conditions at level of catchment stations, tectonic movements, edaphic factors, erosion, etc. constitute a combination having an environmental influence on the quality of water [5]. The geologic constructions in place, the degree of confinement of the water tables and the stay time of water in these geologic constructions represent the main natural factors that explain the chemical variability of underground water [9].

Moreover, from catchment station to the consumer's tap, the water distribution network should not be considered as an inert scheme, but as a real reactor in which innumerable physicochemical and biological interactions occur [10]. This can entail the risks of alteration of the quality of water during transport and storage in comparison to the water produced in the processing plant [10].

The DR Congo overflows $40 \%$ of fresh water (rivers, lakes, Congo River, etc.) and $50 \%$ of African forest which constitute a real receptacle of regulating for the hydrologic cycle [11]. However, because of its socio-political situation always unstable since 1960, the populations know a serious problem with regard to the availability of drinking water. Drinking water supply systems have become decrepit, poorly maintained and often date back to the colonial times [11] [12].

In addition, as this country does not yet have a national water quality control programme, it is difficult to assess the nature and extent of possible water pollution. There are no functional monitoring stations that would allow extrapolated data in order to get an accurate idea on the state and tendencies of the quality of water [13]. Rare studies on the quality of underground and surface water have mostly been undertaken in a prompt way and carried out as part of university 
researches [11]. As an example, we can cite the study by Nienie et al. on the seasonal variability of the physicochemical quality of water from rivers and wells in the suburban region of Kikwit, and which constitutes an original approach in this domain [14].

In order to determine the water quality, scientists assess different microbiological and physicochemical parameters. Thus, germs numbers are usually sought as indicators of faecal contamination. It is for example numbering Total Coliforms include genera that originate in feces (Fecal Coliforms e.g. Escherichia) as well as genera not of fecal origin (non-Fecal Coliforms e.g. Enterobacter, Klebsiella, Citrobacter). However, total coliforms are an indicator of fecal contamination and subsequently of Escherichia coli. That is why for safe drinking water, WHO standard requires zero coliforms per $100 \mathrm{ml}$ of water sample. In addition, Escherichia coli is known to be an indicator of faecal pollution and sign of water treatment failure process [15].

Regarding the physicochemical and aesthetic parameters, a relationship can be found between human health and those parameters: electrical conductivity, turbidity level, colors in water, hardness, concentration of chlorides, sulfate, nitrate, iron-laden waters, fluorides, etc. Thus, in so far as $\mathrm{pH}$ affects the various processes in water treatment that contribute to the removal of viruses, bacteria and other harmful organisms, it can be claimed that $\mathrm{pH}$ has an indirect effect on human health. WHO recommended guideline value for $\mathrm{pH}$ is 6.5 - 8.5 [15].

Secondly, the electrical conductivity of water is used as indirect measure of ionic activity of dissolved mineral salts. This parameter depends on concentration of ions, their nature and temperature of measurement [15].

Moreover, higher turbidity level ( $>5 \mathrm{NTU} / \mathrm{l}$ ) in drinking water may develop gastrointestinal diseases, because contaminants like viruses or bacteria can become attached to the suspended solids. The true colors in water may be due to suspended material, dissolved mineral salts such as ferric hydroxide and manganese, and dissolved organic substances such as humic acids, corrosive material, colored industrial waste or other substances from anthropogenic sources. Color can also indicate the presence of certain runoff or discharges into the water. These colored impurities undermine aesthetic value of drinking water. WHO (1996) recommended level is $15 \mathrm{TCU}$ above which consumer complaints start arising because of unacceptable appearance [15].

Concerning chemical parameters, hard water has high mineral contents. It primarily contains excessive calcium and magnesium metal cations, and sometimes other dissolved compounds such as bicarbonates and sulfates. Water becomes hard during its movement through soil and rock; it dissolves small amounts of these naturally-occurring minerals and carries them into the groundwater. A number of studies in various parts of the world have demonstrated that there is high statistically significant negative association between water hardness and cardiovascular disease [15].

Furthermore, surface water normally has low concentration of chlorides as 
compared to groundwater. Chloride is a chemical the human body needs for metabolism (the process of turning food into energy). It also helps keep the body's acid-base balance. The amount of chloride in the blood is carefully controlled by the kidneys. Chloride ions have important physiological roles. Most sulfate compounds originate from the oxidation of sulfite ores, the presence of shales, and the existence of industrial wastes. Sulfate is one of the major dissolved constituents in rain, but one of the least toxic anions. As early as 1940, it was recognized that consuming waters with high nitrate levels contributed to methemoglobinemia ("blue baby" syndrome). This condition, usually in infants, impairs the ability of blood to carry oxygen. Nitrate toxicities in humans occur through enterohepatic metabolism of nitrates to ammonia, with nitrite being an intermediate [15].

Regarding trace elements, iron in water occurs in the ferrous and ferric forms. The solubility in natural waters is dependent upon the $\mathrm{pH}$ and the oxidation-reduction potential. In reducing conditions; iron exists in the ferrous state. On exposure to air oxidized to the ferric form and with water hydrolyzes to insoluble hydrated ferric oxide that makes iron-laden waters objectionable. As concentrations increase visible orange/brown staining appears and any increase in concentrations may create conditions where complex insoluble oxides, hydroxides and carbonates of iron start precipitating out producing a semi-gelatinous and dense flock carpeting the riverbed. Such conditions are very deleterious to most organisms and can cause serious damage in a river system. Iron in water can cause staining of laundry and porcelain, deposit a slimy coating on the piping. WHO (1996) have recommended the guideline value for iron in drinking water as $0.3 \mathrm{mg} / \mathrm{l}[15]$.

Traces of fluorides occurrence are widespread in waters and higher concentrations are often associated with groundwater sources in areas where fluoridebearing minerals are common. Edmunds and Smedley (1996) have found high fluoride concentrations in groundwater. British Geological Survey (2003) has found that a minor concentration of fluoride in drinking water is beneficial due to having significant mitigating effect against dental cavities. Peterson and Lennon (2004) also reported that mild concentration of fluoride reduces tooth decay and cavities in both children and adults [15].

With nearly a million inhabitants, the city of Butembo knows some particular disastrous facts. In addition to a recurrent insecurity in the region for more than two decades, Ebola virus epidemic disease has come since 2018, exacerbating the exceptional urban expansion. In fact, because of the urban stress, the progressive and regressive gullying increases and influences the availability in water and therefore influences the quality of water. This strong urbanization has resulted in a new use (affectation) of the land with consequences on the urban landscape. There is, thus, a large deficit in the supply of drinking water [16] as well as its spatiotemporal variation, particularly intensifying during the rainy seasons.

In the city of Butembo, the water distributed by the only state-owned company-REGIDESO-is not treated according to international standards because 
of its filtration system on rapid sand, which has remained rudimentary. This leads to the production of troubled water, which makes most of the inhabitants of Butembo consider it unfit for human consumption to choose other water supply points, with all the foreseeable health risks: wells, springs arranged or not, water networks, etc. producing clear and very enamoured water [13].

With regard to the challenge related to water supply, REGIDESO/Butembo, which only has the network of "Kanyangoko" built in colonial times, then erected the network of "Makamba" in 1990, capturing water from the Makamba River whose processing plant, is located in Vulindi, on the road to Butuhe. In order to meet the needs in water of the ever-growing population, the two water supply networks are combined at the level of the SONAS agency, in the municipality of Bulengera. Unfortunately, despite this effort, REGIDESO only serves 15\% - 16\% of the inhabitants of Butembo. This corresponds to a daily production varying volume between 4320 to $4800 \mathrm{~m}^{3}$ for the plant of Makamba and 600 to $700 \mathrm{~m}^{3}$ for the plant of Kanyangoko, i.e. a total average production of 4920 to $5500 \mathrm{~m}^{3}$. This production corresponds to a daily average of 5 to $5.5 \mathrm{~L}$ of water per person compared to a minimum of $100 \mathrm{~L}$ required per inhabitant [17].

Very few studies have been carried out on the variability of water quality in the town of Butembo. The few rare cross-sectional studies have rather concerned water sources and sometimes networks. We can cite, for example, that of Katswangene (2014) who observed that the sample taken from the cell called Base, upstream, contained water of poor bacteriological quality while the other, taken the same day at the fountain Visogho, in the ACEKAVU network, further downstream, i.e. of good bacteriological quality [13].

This is why a study on the variability of spatiotemporal parameters of water quality remains essential in order to better understand the functioning of water conveyance systems and to help improve their management [18]. The target of this study is, thus, to contribute to a better understanding of the spatiotemporal variability of the quality of the water provided by REGIDESO in the city of $\mathrm{Bu}$ tembo to have an idea on the evolution of the quality of the water even after the combination of the water networks in a period of six months.

\section{Material and Methods}

Located in the Northeast of North-Kivu province, in the Eastern part of the DRC, the town of Butembo is large of $190.34 \mathrm{~km}^{2}$. Its geographical coordinates are: $0^{\circ} 08^{\prime} 00^{\prime \prime}$ North latitude, $29^{\circ} 17^{\prime} 00^{\prime \prime}$ East longitude and average altitude: 1800 $\mathrm{m}$. Its relief consists of many hills and valleys with small streams. It knows a moderate equatorial climate impacted by mountains of the type $A f a$ according to Köppen [19], characterized by the alternation of a short dry season from December to February, followed by a short rainy season from March to the endMay, before a short dry season from June to July. Then a short rain season occurs from August to September before the big wet season from October to November [16]. The annual average temperature is of $19.7^{\circ} \mathrm{C}$ recorded in 2017 with 
a minimum of $14.2^{\circ} \mathrm{C}$ and a maximum of $28.6^{\circ} \mathrm{C}$ with an yearly rainfall of 1382 $\pm 153 \mathrm{~mm}$ [19]. Moreover, the climate remains constantly annual and knows very little noticeable disturbance but the length of the rainy season is shortening, undermining urban agriculture production and therefore food security [19].

As far as administration is concerned, Butembo has four municipalities whose appellations and approximate surfaces are as follows: Bulengera $\left(55.18 \mathrm{~km}^{2}\right)$, Kimemi $\left(42.25 \mathrm{~km}^{2}\right)$, Mususa $\left(40.30 \mathrm{~km}^{2}\right)$ and Vulamba $\left(52.61 \mathrm{~km}^{2}\right)$ in Figure 1. [16] [20] [21].

This study is of the descriptive and longitudinal type in a spatiotemporal approach [22]. The population is made up of two REGIDESO networks in the city of Butembo: Makamba and Kanyangoko. The size of our sample is made up of eight sampling sites pinpointed on these networks.

In order to carry out this study, a monthly sampling promotion was carried out on these networks. In total, 48 samples were taken and analysed from January to June 2019. Thus, it was the sampling point located at the (pool) collection station from which the raw water $(R W)$ comes, that is to say before any treatment or disinfection with Chlorine. Then, at the outlet of the processing plant or upstream of the network ( $T W 1)$ and towards the middle of the network (TW2) [23]. In addition, samples taken after mixing water from these two networks were: $T W x 1$ for the sample from the station located just after water combination of the networks, $T W x 2$ for the site located in the middle of the network after combination and $T W x 3$ for the sample located towards the end of that network. Thus, we had constituted a representative sample using the non-random sampling technique by convenience [24].

With regard to the microbiological parameters, seven germs sought were the indicators of faecal contamination, including germs that can be revived at $22^{\circ} \mathrm{C}$ and at $37^{\circ} \mathrm{C}$, the total coliforms and thermo-tolerant (faeces) and Escherichia coli, the streptococci faeces (Enterococci) and the Salmonella-Shigella. These germs were isolated and then counted on gelled and/or selective media by the technique of incorporation or membrane filtration. Incubation temperatures varied between $22^{\circ}, 37^{\circ}$ and $44.5^{\circ} \mathrm{C}$ during 24 or 48 hours depending on the types of germs searched. The Table 1 below provides more details.

The 14 following physicochemical parameters analysed were determined by using a Palintest 7100 brand Photometer [25]: ammonia, ammonium, nitrous nitrogen, nitric nitrogen, chlorides, colour, free copper, total copper, total hardness, iron, fluorine, manganese, nitrates, sulphate.

Given the instability of five parameters over time, it was necessary for us to measure in situ: the concentration of residual active chlorine using a classical Palintest colorimeter, the temperature in the water samples using a industrial thermometer, the turbidity using the classic turbidity meter, and $\mathrm{pH}$ and electrical conductivity using a Hanna multi-pH and conductivity meter. For other twelve chemical parameters, measurements were made using a multi-parameter, a Palin- 
test 7100 brand Photometer in Table 2 [25].

In order to compare the data on the factors of degradation of the quality and those of the spatiotemporal variability of eight sampling sites, the calculation of the averages and the standard deviations of the values of the water quality parameters were carried out in comparison with WHO guidelines [26].

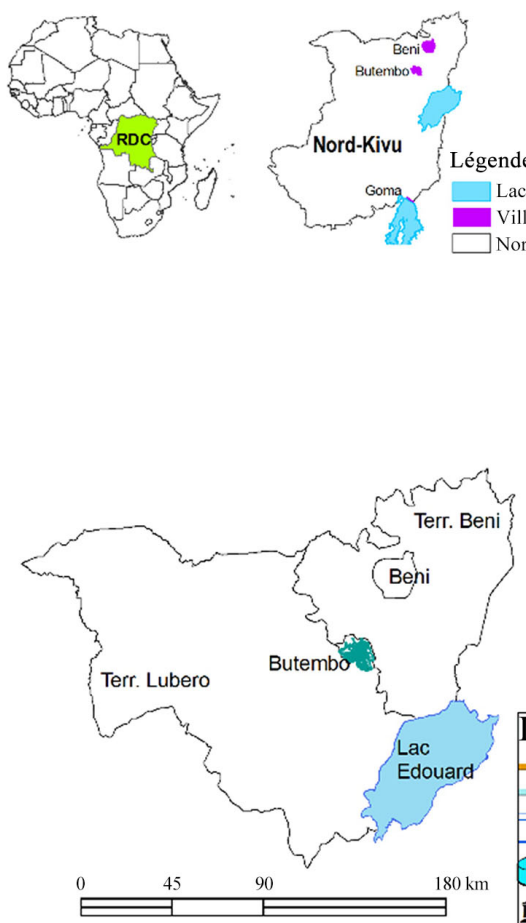

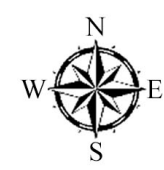

Géospatialisation de sites de prélevement des Echantillons d'eau sur le réseau de la REGIDESO en ville de Butembo Nord-Kivu / RDC

\section{vers Beniet}

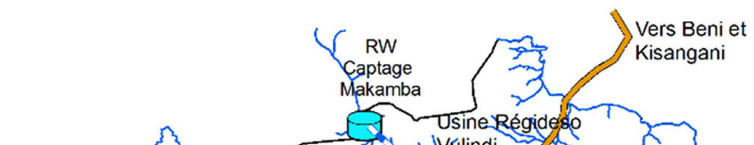

Nord-Kivu
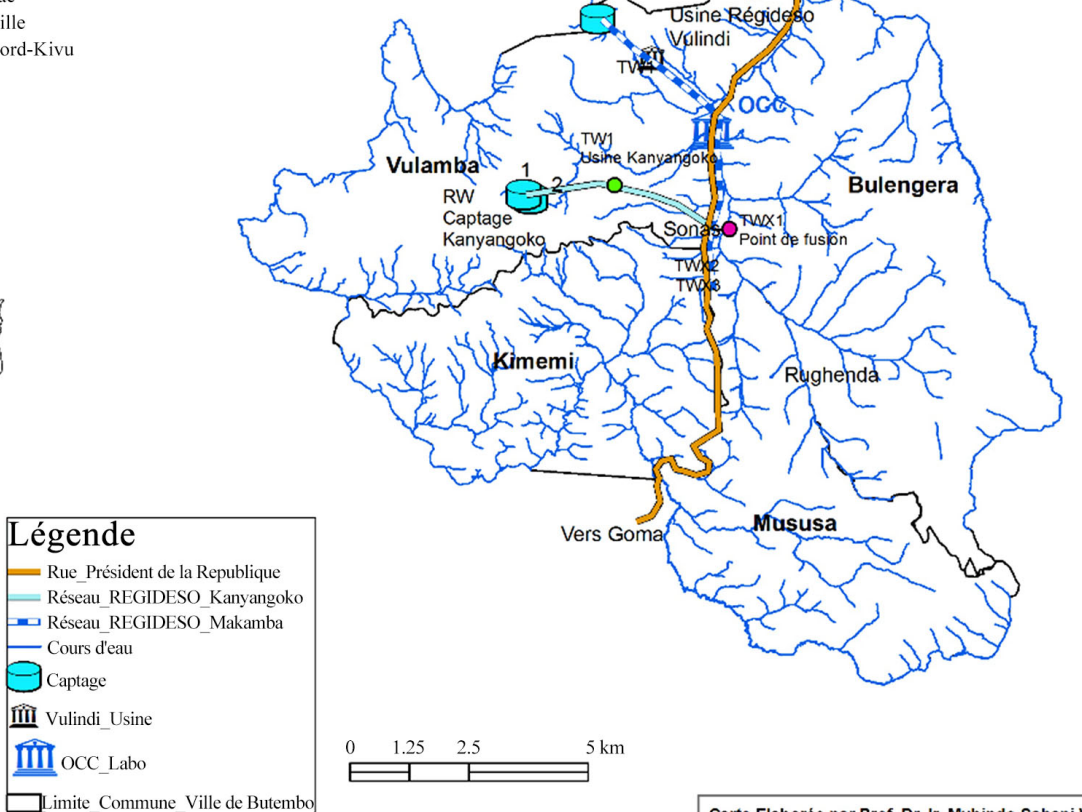

Carte Elaborée par Prof. Dr. Ir. Muhindo Sahani Walere Avril 2021

Email: sahaniwalerem@gmail.com

Figure 1. Localisation of water sampling sites in the city of butembo.

Table 1. Assessing the germs of faecal pollution and the effectiveness of water treatment.

\begin{tabular}{|c|c|c|c|c|c|}
\hline Analysis & Technique & $\begin{array}{l}\text { Sample } \\
\text { Volume }\end{array}$ & Used environment & Incubation & Colonies \\
\hline $\begin{array}{l}\text { Aerobic revivable } \\
\text { microorganisms }\end{array}$ & Incorporation & $1 \mathrm{ml}$ & $\begin{array}{l}23.5 \mathrm{~g} / \mathrm{L} \text { Plate Count Agar (PCA) } \\
35.12 \mathrm{~g} / \mathrm{L} \text { Lactose agar-agar }\end{array}$ & $37^{\circ} \mathrm{C}$ or $22^{\circ} \mathrm{C} / 24$ or 48 hours & Whitish \\
\hline $\begin{array}{l}\text { Total coliforms } \\
\text { Thermo-tolerant }\end{array}$ & in solid media Filtration & $100 \mathrm{ml}$ & $\begin{array}{l}\text { Tergitol with TTC } \\
35.12 \mathrm{~g} / \mathrm{L} \text { Lactose agar-agar }\end{array}$ & $37^{\circ} \mathrm{C} / 24$ hours & Orange yellow \\
\hline $\begin{array}{l}\text { (faecal) Coliforms } \\
\text { Escherichia coli }\end{array}$ & Filtration & $100 \mathrm{ml}$ & $\begin{array}{l}\text { Tergitol with TTC } \\
37.0 \mathrm{~g} / \mathrm{L} \text { Escherichia coli }\end{array}$ & $44.5^{\circ} \mathrm{C} / 24$ hours & Orange yellow \\
\hline & Filtration & $100 \mathrm{ml}$ & Broth + Agar 5\% & $44.5^{\circ} \mathrm{C} / 24$ hours & Whitish \\
\hline $\begin{array}{l}\text { Streptococci of } \\
\text { Group D (Enterococci) }\end{array}$ & Filtration & $100 \mathrm{ml}$ & $\begin{array}{l}46.5 \mathrm{~g} / \mathrm{L} \text { Agar-agar } \\
\text { Slanetz et Bartley }\end{array}$ & $37^{\circ} \mathrm{C} / 24$ hours & Violet-rose \\
\hline Salmonella \& & Filtration & $100 \mathrm{ml}$ & $56.6 \mathrm{~g} / \mathrm{L}$ Xylose & $37^{\circ} \mathrm{C} / 24$ & Red in the \\
\hline Shigella & & & $\begin{array}{l}\text { Lysine Deoxycholate } \\
\text { Agar-XLD }\end{array}$ & Hours & centre \\
\hline
\end{tabular}


Table 2. Reagents and their respective parameters analysed using the Palintest 7100 Photometer.

\begin{tabular}{|c|c|c|}
\hline Analysed parameters & Palintest Reagents & Palintest 7100 Photometer \\
\hline Ammoniac and ammonium & Ammonia $\mathrm{N}^{\circ} 1 \& 2$ Tablets & \\
\hline $\begin{array}{l}\text { Nitrous Nitrogen, nitric } \\
\text { Nitrogen and nitrate }\end{array}$ & Nitratest Kit & \\
\hline Free residual Chlorine & DPD 1 Tablet & \\
\hline Chloride & Acidifying \& Chloride tablets & \\
\hline Colour & - & \\
\hline Free Copper and total Copper & Coppercol N ${ }^{\circ} 1 \& 2$ & \\
\hline Total Hardness & Hardicol Tablets & \\
\hline Iron & Iron HR Tablet & \\
\hline Fluor & Fluoride $\mathrm{N}^{\circ} 1 \& 2$ Tablets & \\
\hline Manganese & Manganese $\mathrm{N}^{\circ} 1 \& 2$ Tablets & \\
\hline Sulphate & Sulphate Tablet & \\
\hline
\end{tabular}

\section{Results and Discussion}

\section{Microbiological parameters}

We presently know that the greatest health risk in relation with drinking tap water is of microbiological order [27]. Thus, with regard to the Table 3 below, the results revealed considerable standard deviations between the average values obtained even for a single parameter. All raw water samples $(R W)$ did not meet any of the WHO guidelines for microbiological quality considered since they came from surface water, which is subject to extreme risks of environmental contamination [28].

Likewise, during this study, there were no sampling sites that provided treated water $(T W)$ of a quality that still fulfils the WHO bacteriological water guidelines. So, for instance, the average numbers of aerobic revivable organisms at $37^{\circ} \mathrm{C}(258.15 \pm 651.6 \mathrm{CFU} / \mathrm{mL})$ very often deviate from these guidelines, even for treated water samples $(T W)$. This makes suppose pollution of human origin or warm-blooded animals [27] [29]. However, it is observed that the averages of aerobic revivable germs at $22^{\circ} \mathrm{C}$ from treated water samples often conform to WHO guidelines (Table 3 ).

Furthermore, the situation is similar for other microorganisms that are bioindicators of faecal pollution and treatment effectiveness. In fact, the noncompliant values are those of: total coliforms with a general average of $286.85 \mathrm{CFU} /$ $100 \mathrm{~mL}$ of water including $3 / 5$ samples (i.e. $60 \%$ ) for the treated water, thermotolerant coliforms with an average of $79.38 \pm 189.6 \mathrm{CFU} / 100 \mathrm{~mL}$ including $4 / 5$ samples, Escherichia coli with an average of $130.21 \mathrm{CFU} / 100 \mathrm{~mL}$ including $4 / 5$ samples (i.e. $80 \%$ ), and enterococci with an average of $27.65 \mathrm{CFU} / 100 \mathrm{~mL}$ including 3/5 samples (i.e. 60\%). Moreover, in terms of the number of Salmonella and Shigella, the average number was $27.65 \mathrm{CFU} / 100 \mathrm{~mL}$, with $1 / 5$ samples (or $20 \%)$ of treated water is out of norms. 
Table 3. General means of bacteriological parameters of water by type of sample.

\begin{tabular}{|c|c|c|c|c|c|c|c|c|}
\hline \multicolumn{2}{|c|}{$\begin{array}{c}\text { Type of } \\
\text { sample } \\
\text { of subtracted } \\
\text { water }\end{array}$} & \multirow{2}{*}{$\begin{array}{c}\begin{array}{c}\text { Number of } \\
\text { Germs revivable } \\
\text { at } 22^{\circ} \mathrm{C} \\
(\mathrm{UFC} / \mathrm{mL})\end{array} \\
3.67 \pm 6.45\end{array}$} & \multirow{2}{*}{$\begin{array}{c}\begin{array}{c}\text { Number of } \\
\text { Germs revivable } \\
\text { at } 37^{\circ} \mathrm{C}^{*} \\
(\mathrm{UFC} / \mathrm{mL})\end{array} \\
6.25 \pm 5.879\end{array}$} & \multirow{2}{*}{$\begin{array}{c}\begin{array}{c}\text { Number of } \\
\text { total Coliforms * } \\
(\mathrm{UFC} / 100 \mathrm{~mL} \text { ) }\end{array} \\
\mathbf{1 8 . 0 8} \pm \mathbf{4 3 . 5 3}\end{array}$} & \multirow{2}{*}{$\begin{array}{c}\text { Number of } \\
\text { Thermo-tolerant } \\
\text { Coliforms } \\
\text { (UFC/100mL) }\end{array}$} & \multirow{2}{*}{$\begin{array}{c}\text { Number of } \\
\text { Escherichia coli* } \\
\text { (UFC/100mL) }\end{array}$} & \multirow{2}{*}{$\begin{array}{c}\text { Number of } \\
\text { Enterococci } \\
\text { (UFC/100mL) }\end{array}$} & \multirow{2}{*}{$\begin{array}{c}\text { Number of } \\
\text { Salmonella \& } \\
\text { Shigella }{ }^{*} \\
\text { (UFC/100mL) } \\
0\end{array}$} \\
\hline$T W 1$ & M & & & & & & & \\
\hline$T W 2$ & M & $9.5 \pm 9.24$ & $48.5 \pm 74.89$ & $8.5 \pm 13.47$ & $1.83 \pm 4.49$ & 0 & 0 & 0 \\
\hline$T W x 1$ & M & $43.5 \pm 79.18$ & $51.17 \pm 81.98$ & $9.83 \pm 21.73$ & $3.17 \pm 5.67$ & $2.5 \pm 5.65$ & $0.17 \pm 0.41$ & $1.167 \pm 2.40$ \\
\hline$T W \times 2$ & M & $36.5 \pm 80.23$ & $13 \pm 22.76$ & $43 \pm 79.33$ & 0 & $4 \pm 9.79$ & 0 & 0 \\
\hline$T W x 3$ & M & $7.17 \pm 11.14$ & $51 \pm 80.23$ & $33.83 \pm 81.41$ & $1.5 \pm 2.51$ & $1 \pm 2.45$ & $0.67 \pm 1.63$ & $0.67 \pm 1.632$ \\
\hline \multirow{2}{*}{ Total } & M & $17.33 \pm 46$ & $29.36 \pm 56.7$ & $21.89 \pm 51.9$ & $3.53 \pm 14.8$ & $1.25 \pm 4.63$ & $0.14 \pm 0.68$ & $0.3056 \pm 1.19$ \\
\hline & MAV & $<100 / \mathrm{mL}$ & $<10 / \mathrm{mL}$ & 0 in $95 \%$ analyses & $0 / 100 \mathrm{~mL}$ & $0 / 100 \mathrm{~mL}$ & $0 / 100 \mathrm{~mL}$ & $0 / 100 \mathrm{~mL}$ \\
\hline
\end{tabular}

Notes: $M=$ Mean; TW1: Treated water taken from the factory outlet; TW2: Treated water taken from the middle of the network; TWx1: Treated water taken after the combination of two networks; TWx2 = Treated water taken from the medium after fusion of two networks; TWx3 = Treated water taken from the extremity after the combination of two networks; MAV = maximum allowable value (OMS). ${ }^{*}$ The numbers in bold are higher than the maximum allowable values.

In view to these results, it is observed that the quality of the water served by REGIDESO does not always conform to the WHO guidelines [27] since even $E$. coli and enterococci are sometimes counted, often far from the processing plant [26] [28]. We believe that this pollution is mainly due to the dilapidated networks dating from the colonial times (1960), in already unacceptable conditions. This finding is consistent with that of Foma et al. who had counted $5.5 \times 10^{5}$ total germs in $100 \mathrm{ml}$ of water from REGIDESO taps in the city of Kisangani [28]. We believe that the works of Kisangani like those of Butembo have already deteriorated and, therefore, following the intrusion of germs from outside, they could multiply in the networks and be responsible for hydric epidemics.

In addition, it was observed that the residual Chlorine concentration seems to decrease as one moves from the treatment plant to the ends of the network (Table 3). This reduction can then leads to the revivification of germs indicatory of pollution and reduce its germicide effect on germs intruding on the network [8] [10]. A similar observation had already been made by Shukuru (2011), in his study on the water supply in the city of Bukavu (South Kivu Province, DRC) and its impact on the diseases of dirty hands [30]. He found that the water supplied by REGIDESO in the city of Bukavu did not meet the quality standards for water intended for human drinking since even $E$. coli had been identified there from the treatment plant until level of taps. In short, this author concluded that the quality of the water from REGIDESO was not stable in all the communes of $\mathrm{Bu}$ kavu following their distance from the treatment plant.

Our results prove sufficiently the considerable incidence of diseases of hydric origin [31] observed in 2019 in the two urban-rural health zones (Butembo and Katwa) which enclose the city of Butembo. Indeed, 674 cases of salmonellosis including typhoid fever cases, 16 cases of amoebic dysentery, 4247 cases of geohelminthiasis, 64 cases of viral hepatitis were counted in the Butembo health zone [32]. In addition, during the same period, in the Katwa health zone, 926 
cases of typhoid fever, 16 cases of amoebic dysentery, 523 cases of geo-helminthiasis, 5 cases of viral hepatitis, 6984 cases of simple diarrhoea versus 250 cases of bloody diarrhoea and 3275 cases of diarrhoea with dehydration were recorded there [33].

\section{Physicochemical parameters of water}

Table 4 gives details of the averages of the physicochemical indicators obtained. Globally, Iron, Nitrate, $\mathrm{pH}$ and Turbidity are the four parameters which have levels that often exceed the maximum admissible values [27] but on the other hand, all 15 parameters are conform of the WHO MAV. So, for instance, the overall ammonium average was lower than the maximum admissible value (i.e. $0.32>0.30 \mathrm{mg} \mathrm{NH}_{4} / \mathrm{L}$ ). As far as Ammonia is concerned, the general average obtained was in accordance with the WHO guidelines, that is to say lower than the maximum admissible value (i.e. $1.67<\mathrm{VMA}=0.5 \mathrm{mg} \mathrm{NH}_{3} / \mathrm{L}$ ). The origin of Ammonia in water is linked to waste, wastewater, which gives a particular odour if the content is greater than $0.5 \mathrm{mg} / \mathrm{L}$ of water. Ammonium reflects pollution of water by organic substances. In fact, the watersheds upstream of the catchment stations of REGIDESO/Butembo are sites with a lot of agricultural waste. In the presence of Hypochlorite, Ammonium gives, in some reactions, Mono-chloramine, a carcinogen product [34].

Table 4. General averages of the values of the physicochemical parameters of treated water by type of sample.

\begin{tabular}{|c|c|c|c|c|c|c|c|}
\hline Type of sample Parameter & $T W 1$ & $T W 2$ & $T W_{x 1}$ & $T W x 2$ & $T W x 3$ & Average & $M A V$ \\
\hline Ammonia & 0.3756 & 0.1240 & 0.204 & 0.1 & 0.032 & 1.67 & $0.5 \mathrm{mg} / \mathrm{L}$ \\
\hline Ammonium & 0.3933 & 0.1717 & 0.2567 & 0.2033 & 0.0367 & 0.32 & $0.3 \mathrm{mg} / \mathrm{L}$ \\
\hline Nitrous Nitrogen & 8.1258 & 4.2083 & 7.7083 & 8.5167 & 4.3167 & 6.83 & $10 \mathrm{mg} / \mathrm{L}$ \\
\hline Nitric Nitrogen & 9.9217 & 10.7983 & 16.975 & 20.2825 & 10.2242 & 13.02 & $15 \mathrm{mg} / \mathrm{L}$ \\
\hline Chloride & 6.275 & 4.8333 & 5.255 & 8.35 & 9.35 & 6.72 & $250 \mathrm{mg} / \mathrm{L}$ \\
\hline Electric Conductivity & 67.0833 & 58.3333 & 63.3333 & 53.3333 & 50 & 59.86 & $10^{3} \mu \mathrm{s} / \mathrm{cm}$ \\
\hline Colour & 4.5833 & 13.3333 & 22.5 & 0.8333 & 15 & 10.14 & $15 \mathrm{mg} \mathrm{Pt} / \mathrm{L}$ \\
\hline Free Copper & 0.0817 & 0.0833 & 0.0667 & 0.0267 & 0.0683 & 0.07 & $2 \mathrm{mg} / \mathrm{L}$ \\
\hline Total Hardness & 20.8333 & 27.8333 & 30.8333 & 27.5 & 25 & 25.47 & $200 \mathrm{mg} / 1$ \\
\hline Iron $^{\star}$ & 0.365 & 0.295 & 0.4067 & 0.2267 & 0.475 & 0.36 & $0.3 \mathrm{mg} / 1$ \\
\hline Fluor & 0.51 & 0.445 & 0.4367 & 0.4983 & 0.3667 & 0.46 & $1.5 \mathrm{mg} / \mathrm{L}$ \\
\hline Manganese & 0.0085 & 0.075 & 0.0083 & 0 & 0.1917 & 0.05 & $0.5 \mathrm{mg} / \mathrm{L}$ \\
\hline Nitrate $^{*}$ & 45.9167 & 42.0833 & 42.5 & 107.3833 & 51.8333 & 55.94 & $50 \mathrm{mg} / \mathrm{L}$ \\
\hline $\mathrm{pH}^{*}$ & 6.0833 & 5.7833 & 5.9833 & 6.1667 & 6.1 & 6.03 & $6.5-8.5$ \\
\hline Sulphate & 9.5 & 8.3333 & 17.8333 & 6.1667 & 11 & 10.39 & $250 \mathrm{mg} / \mathrm{L}$ \\
\hline Water Temperature & 19.3167 & 21.55 & 22.4167 & 21.9833 & 22.15 & 21.12 & $8^{\circ} \mathrm{C}-15^{\circ} \mathrm{C}$ \\
\hline Turbidity * & 7.8667 & 5.6833 & 6.35 & 5.2167 & 6.4167 & 6.57 & 5 N.T.U. \\
\hline
\end{tabular}

Notes: $M=$ Average; TW1: Treated water taken from the factory outlet; TW2: Treated water taken from the middle of the network; TWx1: Treated water taken after the merger of two networks; TWx2 = Treated water taken from the medium after fusion of two networks; TWx3 = Treated water taken from the end after merging two networks; MAV = maximum allowable value (OMS). ${ }^{\star}$ The numbers in bold are higher than the maximum allowable values. 
Concerning Ammoniac Nitrogen (Ammonium), Nitrous Nitrogen and Nitric Nitrogen (Table 4), their averages remained in accordance with WHO guidelines, i.e. $0.32<1.5 \mathrm{mg} \mathrm{N} / \mathrm{L}$, respectively; $6.63<10 \mathrm{mg} / \mathrm{L}$ and $13.02<15 \mathrm{mg} / \mathrm{L}$. However, the Nitric Nitrogen content exceeded the MAV, i.e. $16.975 \mathrm{mg} / \mathrm{LN}$ for the treated water withdrawn after combination of two networks $(T W x 1)$ of $20.2825 \mathrm{mg} \mathrm{N} / \mathrm{L}$ and $10.2242 \mathrm{mg} / \mathrm{L}$ towards the end of the combined networks for the treated water taken from the middle after water fusion from the networks studied ( $T W x 2)$.

In addition, the active free Chlorine protects the water against subsequent contamination in the distribution networks for a limited period following the initial disinfection. Here, the average obtained is $0.23<5 \mathrm{mg} / \mathrm{L}$, so the disinfection process may not always have been effective. Moreover, the content of this disinfectant seems to decrease from the treatment plant to the end of the network, thus reducing its bactericidal effect. This would explain the considerable microbial contents observed in the samples of water already treated, as observed by Shukuru (2011) at REGIDESO in the city of Bukavu [30].

Furthermore, the average concentration of Chloride was $6.72<250 \mathrm{mg} / \mathrm{L} \mathrm{NaCl}$, this shows that the water distributed by REGIDESO/Butembo remains soft and thus conforms to the WHO guidelines. Of natural origin (34), human (urine), industrial origin, Chloride is responsible for the brackish taste of drinking water when its content is higher [34].

In addition, derived from dissolved solids, electrical conductivity is an indicator of the presence of dissolved solids; it reflects the mineral charge of the water [34]. Higher, it affects the savour of water. The observed average was $59.86<1000$ $\mu \mathrm{s} / \mathrm{cm}$ during the six months of observation and therefore remains in accordance with the WHO guidelines [27]. Likewise, the colour of the water has remained within criterions, i.e. $10.14<15 \mathrm{mg} \mathrm{Pt} / \mathrm{L}$. The same is true for free Copper with an average of $0.07<2 \mathrm{mg} / \mathrm{L} \mathrm{Cu}$ and total Copper with $0.16<2 \mathrm{mg} / \mathrm{L} \mathrm{Cu}$. It is the same with regard to the total hardness (Hydrotimetric Title) which has remained in conformity during our study. We have observed the conformity of the average, which was very low compared to the MAV, i.e. $25.47<200 \mathrm{mg} / \mathrm{l}$. It is known that hard water causes scaling in distribution systems and excessive soap consumption, while soft water can cause corrosion of pipes [34].

Our analyses indicate that the general mean of Iron content is $0.36>0.3 \mathrm{mg} / \mathrm{l}$, this may explain the red coloration of REGIDESO water often observed by users. Iron originates from rocks, coagulants (ferric Sulphate /ferric Chloride) and, in high content, gives the red colour, a metallic savour and the smell of rotted fish. In addition, it is known that ferruginous bacteria can clog pipes [34].

In contrast, Fluoride, at a content of $<1.5 \mathrm{mg} / \mathrm{L}$ of water, helps prevent tooth decay. But if high, it causes fluorosis [26]. Thus, the analyses have revealed only values lower than the MAV, i.e. $0.46<1.5 \mathrm{mg}$ F/L. This average conforms to the literature, which sustains that, being surface water, it very rarely exceeds $1 \mathrm{mg} / \mathrm{L}$ [26]. Thus, the risk of fluorosis appears to be minimal in our milieu of study. Likewise, our results indicate the compliance of Manganese content with regard 
to the WHO guidelines. It is known that Manganese comes from pyrite soils and agricultural soils. When high, water has a dark colour and infects its savour. Likewise, the general average concentration was $0.05<0.5 \mathrm{mg} \mathrm{Mn} / \mathrm{L}$ [27].

On the other hand, the average of Nitrate content was higher than the MAV, i.e. $55.94>50 \mathrm{mg} \mathrm{NO}-/ \mathrm{L}$, not in accordance with the WHO guidelines. The Nitrate content in underground and surface waters comes from runoff from agricultural land, leaking of septic tanks, and sewers (33). Thus, Nitrate can present a health risk by converting itself to Nitrites into the body and can pose such a very high danger for young children of a few months (26). Thus, it can lead to methaemoglobinemia, induce a risk of cancer, the deposition of fats and splenic haemorrhage. These increases are observed especially in urban areas (waste from factories, lots of latrines, etc.) and in areas of intensive agriculture using a lot of fertilizer [34]. The catchment of REGIDESO Butembo stations seem to meet these urban and agricultural conditions. This would explain the non-compliance with the WHO guidelines [27].

Likewise, the $\mathrm{pH}$ of all our analysed samples is non-compliant and tends to remain acidic. Indeed, the $\mathrm{pH}$ was always lower than the MAV, i.e. $6.03<6.5$ 8.5. The $\mathrm{pH}$ reflects changes in the quality of sources of water. In the network, the acidic $\mathrm{pH}$ is responsible for corrosion, a risk of release of plumbing elements and the formation and speciation of disinfection by-products with carcinogenic risk [26]. This is why the raw water is always limed at the level of the catchment station before being conducted to coagulation-flocculation, particularly during dry seasons [34].

As for Sulphates, the general average was much lower than the MAV, i.e. 10.39 $<250 \mathrm{mg} / \mathrm{L}$ therefore fulfils the WHO guidelines [27]. Sulphates take their natural origin in gypsum rocks, but also industrial origin following the use of chemical fertilizers and detergents. They have a laxative effect. Thus, they cannot contribute to making the water analysed corrosive to concrete because their concentration is very $<250 \mathrm{mg} / \mathrm{L}[34]$.

Between $8^{\circ} \mathrm{C}-15^{\circ} \mathrm{C}$, the water temperature is well tolerated by most consumers. However, the average was observed to be $21.12^{\circ} \mathrm{C}>15^{\circ} \mathrm{C}$ according to the WHO [27]. High water temperature $\left(20^{\circ} \mathrm{C}-30^{\circ} \mathrm{C}\right)$ can cause problems of savour, odour, colour and corrosion [33]. It can lead to the formation and degradation sub-products of disinfection and additionally affect the $\mathrm{pH}$ of the water. It can then be responsible for the microbial growth sometimes observed in the network after treatment [4] and significantly influence the quality of the water.

Finally, the average of turbidity was high compared to the MAV, i.e. $6.57>5$ N.T.U. even for treated water averages [27]. We know that this parameter is an indicator of microorganisms and the quantity of natural organic matter: clay, lime particles, human activities. Changes in turbidity after rains are an indicator of contamination of untreated water. Turbidity originates from suspended materials, colloids, dissolved materials and could be a vector of all microbes, para- 
sites, and others [35]. Normally it can be seen with the naked eye and it measures the clarity of the water. It can be due to a deficit in the system of water filtration or to a mobilisation of sediments, mineral precipitates or a biofilm in the network... As for acceptability, this turbidity is responsible for the refusal of most of the inhabitants of Butembo to drink water from REGIDESO to move towards other supply systems, but whose quality of water is still far from guaranteed.

\section{Evolution of the number of indicator microorganisms during the study} period.

With regard to the graphics (Figure 2) below, the numbers of bio-indicators tend to decrease from January to February, grow from March to April to decrease again in May and then relapse in June 2019. Nevertheless, the mean numbers of germs revivable at $22^{\circ} \mathrm{C}$ and $37^{\circ} \mathrm{C}$ rise very much in June. The climatic conditions observed (rainfall, temperature) and human factors such as the chlorination and liming process, maintenance work on the networks, etc. during this period could well explain this phenomenon. Further study may well elucidate this phenomenon.

\section{Evolution of the physicochemical parameters of water during the study} period.

With regard to the graphics (Figure 3) below, the physicochemical parameters that the shows main monthly fluctuations are, for example, the evolution of nitrates concentration is as following: $42.70,77.00,38.48,39.05,44.90,93.50 \mathrm{mg} / \mathrm{L}$ respectively from January to June 2019. The same observation is done for these parameters: total hardness, electrical conductivity, nitric nitrogen, etc. However, many other parameters remained with very low fluctuations, for example, manganese, sulphate, chloride, $\mathrm{pH}$, turbidity, water temperature, etc. Further study may well elucidate this phenomenon.

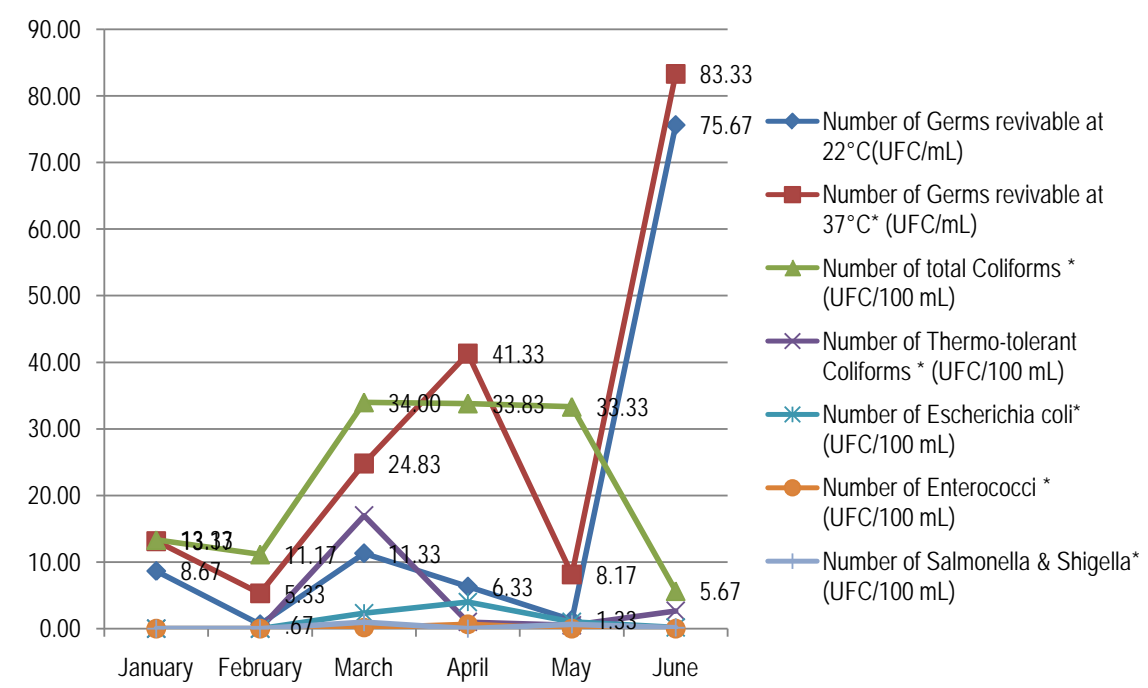

Figure 2. Monthly fluctuations in the number of bio-indicator microorganisms (from January to June 2019). 


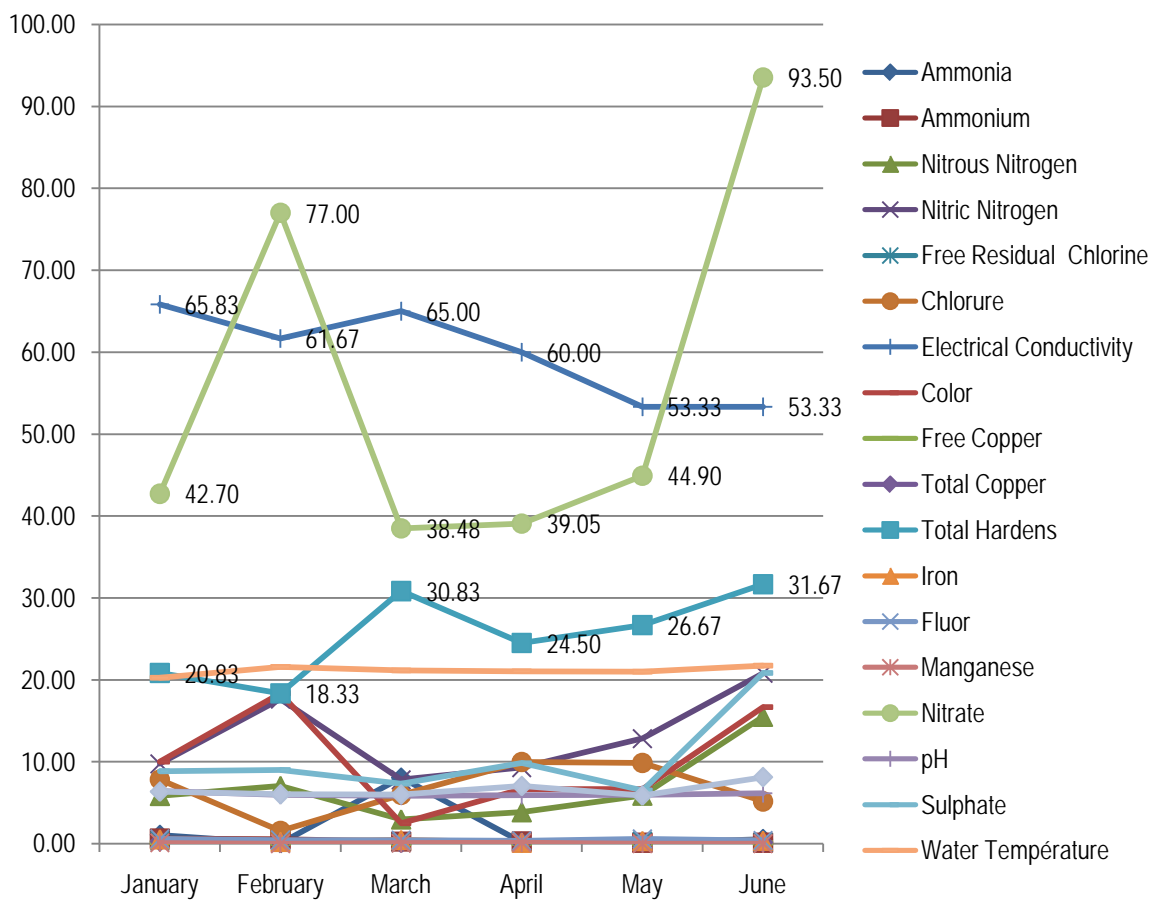

Figure 3. Monthly fluctuations in the physicochemical parameters of water (from January to June 2019).

\section{Conclusions}

In water management, drinkability must be everywhere on the water supply network and always be maintained for the health of the consumer. The quality of water in a network of distribution is significantly influenced by parameters from raw water, transport and the water environment throughout its distribution as well as the water combination of many networks. The distribution network [23] is therefore a site of physicochemical and biological interactions which can lead to the deterioration of the quality of the treated water [10] [23]. This is why the supply of drinking water remains a perpetual concern for managers of supply systems and for the health personnel [10] [36]. The workers of REGIDESO/ Butembo should supervise these systems more and regularly carry out adequate physicochemical and bacteriological analyses in order to correct, at the appropriate time, the parameters that have evolved negatively in order to maintain water potable up to the consumer's tap [5].

During this study, eight samples of water were analysed monthly at the collection site and in the laboratory. And generally, the results are as follows:

1) There were no withdrawal sites of treated water that always remained in compliance with the bacteriological water quality guidelines according to the WHO guidelines [27]. The risk is so serious that even E. coli and Enterococci have been found in the tap water, often far from the treatment plant. It is therefore necessary to intensify the supervision of the networks and to carry out regular microbiological analysis of the water served to the population in order to make corrective processes at the appropriate time and to study the possibility of carrying out 
secondary chlorination on the network.

2) As for the averages of the physicochemical parameters, eight of 19 , or $28.10 \%$, remained in compliance with WHO guidelines. These are: Chloride $(6.72 \mathrm{mg} / \mathrm{L})$, electrical conductivity $(59.86 \mathrm{mg} / \mathrm{L})$, free Copper $(0.07 \mathrm{mg} / \mathrm{L})$, total Copper $(0.16$ $\mathrm{mg} / \mathrm{L})$, total hardness $(25.47 \mathrm{mg} / \mathrm{L})$, Fluorine $(0.46 \mathrm{mg} / \mathrm{L})$, Manganese $(0.05 \mathrm{mg} / \mathrm{L})$, and Sulphate $(10.39 \mathrm{mg} / \mathrm{L})$. On the other hand, seven parameters have presented a general average far from the maximum admissible values. These are: Ammonia $(1.67>0.5 \mathrm{mg} / \mathrm{L})$, Ammonium $(0.32>0.3 \mathrm{mg} / \mathrm{L})$, Iron $(0.36>0.3 \mathrm{mg} / \mathrm{l})$, Nitrate $(55.94>50 \mathrm{mg} / \mathrm{L}), \mathrm{pH}(6.03<6.5-8.5)$, Water Temperature $\left(21.12>8^{\circ} \mathrm{C}-\right.$ $15^{\circ} \mathrm{C}$ ) and Turbidity (6.57 $>5$ N.T.U.). Other parameters have shown considerable variability over time and space. In short, the acidic $\mathrm{pH}$, high turbidity, Iron and Nitrate concentration levels were observed as the main physicochemical problems in treated water of REGIDESO/ Butembo.

3) As for the variability over time, the numbers of bio-indicators tended to decrease from January to February, increase from March to April and decrease again in May and then relapse in June 2019. But, the mean numbers of germs revivable at $22^{\circ} \mathrm{C}$ and $37^{\circ} \mathrm{C}$ rise very much in June. The seasons experienced during this period could well explain this phenomenon.

4) Moreover, the physicochemical parameters that the shows main monthly fluctuations are, for example, the evolution of nitrates concentration is as following: $42.70,77.00,38.48,39.05,44.90,93.50 \mathrm{mg} / \mathrm{L}$ respectively from January to June 2019. The same observation is done for these parameters: total hardness, electrical conductivity, nitric nitrogen, etc. However, many other parameters remained with very low fluctuations, for example, manganese, sulphate, chloride, $\mathrm{pH}$, turbidity, water temperature, etc. However, additional observations would be essential to better elucidate their possible seasonality.

\section{Acknowledgements}

The authors extend their gratitude to the responsible of the Office "Congolais du Contrôle (OCC)"/Butembo; of REGIDESO/Butembo; from CAUB, CEPROSSAN and UCG/Butembo laboratories.

\section{Conflicts of Interest}

The authors declare no conflicts of interest regarding the publication of this paper.

\section{References}

[1] Action Contre la Faim (2006) Eau-Assainissement-Hygiène pour les populations à risque. Hermann, Paris, 95-745.

[2] Large, A. (2010) Protection de la santé publique et bon état des eaux: Complémentarités et incompatibilités de 4 directives Européennes: Synthèse documentaire. Office National de l'Eau et des Milieux Aquatiques (ONEMA), Agences de l'eau, Paris, $57 \mathrm{p}$.

[3] OMS (2004) Directives de qualité pour l'eau de boisson. Recommandations. Troisième Edition. Volume 1. Genève, $110 \mathrm{p}$. 
[4] Blokker, E.J.M., Furnass, R.W., Machell, J., Mounce, R.S., Schaap, G.P. and Boxall, B.J. (2016) Relating Water Quality and Age in Drinking Water Distribution Systems Using Self-Organising Maps. Environments, 3, 10. https://doi.org/10.3390/environments3020010

[5] Damo, R. and Icka, P. (2013) Evaluation of Water Quality Index for Drinking Water. Polish Journal of Environmental Studies, 22, 1045-1051.

[6] Mabrouki, Y., Taybi, A.F., Bensaad, H. and Berrahou, A. (2016) Variabilité spatiotemporelle de la qualité des eaux courantes de l'Oued Za (Maroc Oriental). Journal of Materials and Environmental Science, 7, 231-243.

[7] Association Internationale de Techniciens, Experts et Chercheurs [AITEC] (2013). L'eau et l'assainissement dans les villes du monde. http://www.globenet.org/aitec/chantiers/environnement/eauassinissement.htm

[8] Grondin, P.M. (2005) Chloration en milieu rural dans les pays en voie de développement. Actes de la réunion organisée par le pS-Eau (réédition 2005). Cahier $\mathrm{N}^{\circ} 10$. Paris. http://www.pseau.org

[9] Ministère de l'Environnement et de la Lutte contre les changements climatiques du Québec (2020) Rapport sur l'état des ressources en eau et des écosystèmes aquatiques du Québec.

https://www.environnement.gouv.qc.ca/eau/rapport-eau/index.htm

[10] Gauthier, F. (2002) Biofilm et qualité de l'eau potable au cours de sa distribution. Mémoire DESS QGE. Université de Picardie, Amiens, 64 p.

[11] PNUE (2011) Problématique de l'Eau en République Démocratique du Congo: Défis et Opportunités. Rapport Technique, Nairobi, 57-94.

[12] Coopération Technique Belge [CTB] (2009) Enjeux et perspectives de la gestion de l'eau potable en milieu rural: Expériences de la coopération belge dans le domaine de l'hydraulique rurale et périurbaine en Afrique. Agence Belge de Développement, Bruxelles, 58 p.

[13] Katswangene, P.K. (2014) Contribution à la détermination des bactéries indicatrices de la contamination fécale et efficacité de traitement de l'eau de boisson en ville de Butembo et ses environs (R.D.-Congo). Mémoire de Diplôme d'Etudes Supérieures. Dpt Sci. Biotechnologiques, Fac. Sci. UNIKIS, 121 p.

[14] Nienie, A.B., Sivalingam, P., Laffite, A., Ngelinkoto, P., Otamonga, J.P., Matand, A., et al. (2017) Seasonal Variability of Water Quality by Physicochemical Indexes and Traceable Metals in Suburban Area in Kikwit, Democratic Republic of the Congo. International Soil and Water Conservation Research, 5, 158-165. https://doi.org/10.1016/j.iswcr.2017.04.004

[15] Malik, M.A., Azam, M. and Saboor, A. (2010) Water Quality Status of Upper KPK and Northern Areas of Pakistan. Pakistan Council of Research in Water Resources, Water Resources Research Centre, Peshawar Ministry of Science and Technology, Publication No. 142-2010.

[16] Sahani, M. (2012) Le contexte urbain et climatique des risques hydrologiques de la ville de Butembo (Nord-Kivu/RDC). Thèse de doctorat, Collège de doctorat en Géographie, Fac. Sci. Université de Liège, 237 p.

[17] Emmanuel, E. (2009) Evaluation des risques sanitaires et ecotoxicologiques liés aux effluents hospitaliers. Institut National des Sciences Appliquées de Lyon, Thèse de doctorat, Lyon, $260 \mathrm{p}$.

[18] La Jeunesse, I. and Quevauviller, P. (n.d.) Le changement climatique et les réseaux écologiques: Impacts, adaptation, législation et avancées scientifiques. Edition. Lavoisier.fr., 20. 
[19] Sahani, M., Moeyersons, J., Vandecasteele, I., Trefois, P. and Ozer, P. (2012) Evolution des caractéristiques pluviométriques dans la zone urbaine de Butembo (RDC) de 1957 À 2010. Geo-Eco-Trop, 36, 121-136.

[20] Kitakya, P.A. (2007) Interactions entre la gestion foncière et l'économie locale en région de Butembo, Nord-Kivu, République Démocratique du Congo. Thèse de doctorat, Université Catholique de Louvain, 262 p.

[21] Rapport annuel du Administration du Territoire (2018) Ville de Butembo, NordKivu, République Démocratique du Congo.

[22] Ziegler, D. (2012) Formation en recherche documentaire. Bibliothécaire-Informationniste. Centre de documentation du CHUM. http://www.ebm.lib.ulg.ac.be/prostate/typ etud.htm\#rapport

[23] Scheili (2015) Variabilité spatio-temporelle de la qualité de l'eau potable des petits réseaux: Facteurs explicatifs et développement d'outils de gestion. Thèse de doctorat, Faculté d'aménagement, d'architecture, d'art et de design, Université Laval, 172 p.

[24] Okitolonda, W.E.P. (2008) Méthodologie de la recherche. Module 4. Université de Kinshasa, Ecole de Santé Publique, Kinshasa, 181 p.

[25] Palintest (2019) Water Analysis Technologies. Kingsway, Team Valley Gateshead Tyne \& Wear NE11 0NS England. http://www.palintest.com

[26] Masivi, O.M. (2015) Travail de recherche scientifique en sept étapes. éd. FRIDI, UNILUK, $160 \mathrm{p}$.

[27] Rodier, J., Legube, B., Merlet, N., et al. (2009) L'analyse de l'eau. 9th Edition, Dunod, Paris, $1526 \mathrm{p}$.

[28] Foma, M., Tabu, B. and Liya, S.M. (1986) Détection et dénombrement des coliformes et streptocoques fécaux dans les eaux de consommation de la ville de Kisangani (République du Zaïre). Tropicultura, 4, 49-52.

[29] Travel, A., Chevalier, D., Merlet, F. and Fulbert, L. (2007) Facteurs de variation de la qualité bactériologique de l'eau en élevage de dindes. TeMA no 3, juillet/août/ septembre, $11 \mathrm{p}$.

[30] Shukuru, S.F. (2011) Approvisionnement en eau dans la ville de Bukavu et son impact sur les maladies de mains sales. Université officielle de Bukavu, Mémoire de Licence en santé publique.

http://www.memoireonline.com/04/12/5632/m Approvisionnement-en-eau-dans-1 a-ville-de-Bukavu-et-son-impact-sur-les-maladies-de-mains-sales1.html\#toc1

[31] Groupe Scientifique de l'eau (2002) Entérocoques et streptocoques fécaux in Fiches synthèses sur l'eau potable et la santé humaine. Institut National de Santé Publique du Québec, Québec, 2 p.

[32] Archives de la Zone de santé de Butembo (2019) Rapport annuel 2019. Butembo, Nord-Kivu, RDC.

[33] Archives de la Zone de santé de Katwa (2019) Rapport annuel 2019. Butembo, Nord-Kivu, RDC.

[34] Centre for Affordable Water and Sanitation Technology [CAWST] (2013) Introduction à l'Analyse de Qualité de l'Eau de Boisson. Calgary, Alberta, T2E 8H6, 197 p. http://www.cawst.org

[35] N'diaye, A.D., Mint Mohamed, S.K. and Kankou, M.O.S.O. (2013) Contribution à l'étude de la qualité physicochimique de l'eau de la rive droite du fleuve Sénégal. Larhyss Journal, 12, 71-83.

[36] Ellioua, M. (2010) Etude de l'évolution spatio-temporelle de certains paramètres de qualité dans le réseau d'eau potable de la RADEEMA (Régie Autonome de Distri- 
bution d'Eau et d'Electricité de Marrakech). Mémoire du Mastère Spécialisé en Management et Ingénierie des Services d'Eau et d'Assainissement, Ecole Nationale du Génie de l'Eau et de l'Environnement de Strasbourg (ENGES), Marrakech, 65 p. 